\title{
INFLUENCE OF LIGHT QUALITY ON FLUCTUATING ASYMMETRY OF BILATERAL TRAITS OF FORCED PARSLEY LEAVES
}

\author{
Sergey Rakutko ${ }^{1}$, Elena Rakutko ${ }^{1}$, Dmitriy Kaposhko ${ }^{2}$, Alexander Vaskin ${ }^{2}$, Andrey Tranchuk ${ }^{3}$ \\ ${ }^{1}$ Institute for Engineering and Environmental Problems in Agricultural Production - IEEP, Russia; \\ ${ }^{2}$ Saint-Petersburg State Agrarian University, Russia; ${ }^{3}$ Riga Technical University, Latvia \\ sergej1964@yandex.ru
}

\begin{abstract}
Under the influence of radiation energy the plants feature a number of physical effects, which lead to regulatory and other processes, up to gene expression. Single photons of irradiation absorbed by plant organisms initiate quick and visible transformation of the morphological and physiological state of plants. The most striking manifestation of developmental stability of a biological object at macro level is fluctuating asymmetry, which involves slight and random deviations in bilateral (mirror) traits. The fluctuating asymmetry is known to be minimal only under optimal environmental conditions but it increases under any stress conditions. If non-optimal irradiation parameters, affecting the plants, are considered a stress factor, the fluctuating asymmetry level may be taken as an indicator of the plant status for assessment of effectiveness and sustainability of the plant growing process under artificial conditions. We conducted several studies to identify the relationship between the level of fluctuating asymmetry of forcing parsley leaves (Petroselinum crispum var. tuberosum) and the light quality of different radiation sources. Two sources with equal photosynthetic photon flux density of $80 \mu \mathrm{mol} \cdot \mathrm{m}^{-2} \cdot \mathrm{s}^{-1}$ in the growing zone were used: a LED irradiator, with the ratio of radiation density (blue $\mathrm{k}_{\mathrm{B}} 400-500 \mathrm{~nm}$, green $\mathrm{k}_{\mathrm{G}}$ 500-600 nm and red $\mathrm{k}_{\mathrm{R}} 600-700 \mathrm{~nm}$ ) being $k_{B}: k_{G}: k_{R}=31 \%: 9 \%: 60 \%$, and high pressure sodium lamps with the ratio of $k_{B}: k_{G}: k_{R}=9 \%: 54 \%: 37 \%$. The length of the first leafstalks of the first order extending from the rachis was considered as a bilateral trait. The size-dependence of this trait was not found. Statistical analysis of the (L-R) variant distribution by the Wilcoxon test showed the fluctuating type of asymmetry. The effect of irradiation light quality on the leaf fluctuating asymmetry level was revealed. The higher fluctuating asymmetry level was found to correspond to smaller values of parsley productivity.
\end{abstract}

Keywords: phytomonitoring, indoor plant lighting, light quality, developmental instability, fluctuating asymmetry, Petroselinum crispum var. tuberosum.

\section{Introduction}

The flow energy in the range of photosynthetically active radiation (PAR) with a wavelength from 400 to $700 \mathrm{~nm}$ is the basis of the indoor plant lighting, i.e. growing plants under artificial light sources. In order to maximize the productivity of cultivated plants with the minimum energy inputs an additional artificial optical radiation is used. It provides an opportunity to vary many radiation parameters, such as intensity, duration, light quality, etc. The latter has an essential effect on the growth, development and physiology of plants [1].

Under the influence of irradiation energy the plants feature a number of physical effects, which lead to regulatory, adaptive and other processes, up to the gene expression. Single photons of irradiation absorbed by plant organisms initiate quick and visible transformation of the morphological and physiological condition of plants [2].

As a living organism, a plant is characterized by the property of environmental stability, which allows to form an optimal phenotype in the course of plant development. Inadequate quality of growing conditions results in unstable development of plants that is a consequence of interaction of random events in the plant body and its ability to follow accurately the program coded in the genotype.

The most striking manifestation of the developmental stability of a biological object at the macro level is fluctuating asymmetry (FA), which involves slight and random deviations in bilateral (mirror) traits. It is known that FA is minimal only under optimal environmental conditions but it increases under any stress [3]. If the non-optimal irradiation parameters, affecting the plants, are assumed to be a stress factor, it is possible to take the FA level as an indicator of the plant status to assess the effectiveness and ecological compatibility of the plant growing process under controlled conditions.

The FA is known to closely correlate with environmental friendliness of both natural and controlled plant growing conditions $[4 ; 5]$. The aim of the research was to confirm the hypothesis on the influence of differences in the light quality of radiation on the level of FA of forced parsley leaves. 


\section{Materials and methods}

To conduct the experiment on forcing the green crop under the indoor plant lighting the root parsley Urozhainaya (Petroselinum crispum var. tuberosum) was grown in the summer of 2015 outdoors in a bed. The crop tending included thinning of seedlings, inter-row hoeing, weeding, watering, and fertilising. The final distance between the plants in a row in late August was 5-7 cm. The roots were removed in early October before it set in to freeze. The tops were cut off at the crown. The parsley roots were stored in a dark basement with the air temperature not higher than $+5^{\circ} \mathrm{C}$ and the relative humidity of 60 to $70 \%$. Their preservation was $100 \%$. A single root weight was in the range from $11.46 \mathrm{~g}$ to $79.42 \mathrm{~g}$. In our preliminary study [6] it was found that the correlation between the size of forced leaves and the weight of roots was very weak irrespective of the light quality; so to conduct the experiment all the 50 roots were taken.

The roots were divided into two batches to be grown under radiation with different light quality in such a way that the average weight of roots in both batches was almost equal. The old leaves as well as too long root tips were cut off, with the apical bud being left, so that the planting material was of the same length. The roots were planted on 25.02. 2016 in polypropylene containers with the capacity of $663 \mathrm{~cm}^{3}$ each. The containers were filled with high-bog sphagnum peat with $\mathrm{pH} 3.6,10 \%$ decomposition degree, $55 \%$ moisture content and low content of major nutrients. Peat acidity was neutralized with chalk to $\mathrm{pH}$ 6.2. The peat was supplied with the main nutrients and microelements. The crown and neck of parsley were left uncovered. The peat around the roots was compacted and watered. The containers were placed in the dark with the air temperature $+14{ }^{\circ} \mathrm{C}$ for branch roots to form. During the growing period the air temperature was maintained at $+18{ }^{\circ} \mathrm{C}$, the humidity - at $60 \%$ [7]. The roots were watered with small portions of water to avoid the crown getting wet. The green part was cut off right near the root. The exposure time per day (photoperiod) was $8 \mathrm{~h} \mathrm{[8].}$

The experiment was carried out in a room without natural light, which was divided into two zones by a light-tight partition. The plants were placed on the benches in $0.45 \times 0.90 \mathrm{~m}$ trays under the irradiators, with the exposure uniformity being not less than $20 \%$. Altogether 25 containers with plants were placed in each zone. The photosynthetic photon flux (PPF) of $80 \mu \mathrm{mol} \mathrm{s} \mathrm{s}^{-1} \mathrm{~m}^{-2}$ was maintained by adjusting the suspension height of irradiators over the plant tops. In the first zone five LED L-Fito irradiators of Ledel Company were fixed on the bars at an interval of $0.3 \mathrm{~m}$ and placed at a height of $1.17 \mathrm{~m}$ above the plant tops. An irradiator had a single capacity of $60 \mathrm{~W}$, light distribution type $\mathrm{D}$, and consisted of 10 blue, 10 white and 30 red light emitting diodes. The ratio of the emission intensity between three spectral bands (blue $k_{B} 400-500 \mathrm{~nm}$, green $k_{G} 500-600 \mathrm{~nm}$ and red $k_{R} 600-$ $700 \mathrm{~nm}$ ) was $k_{B}: k_{G}: k_{R}=31 \%: 9 \%: 60 \%$. In the second zone an irradiation facility Reflux with high pressure sodium lamps (HPS) was used. The light quality was $k_{B}: k_{G}: k_{R}=9 \%: 54 \%: 37 \%$.

The reason for the choice of radiation sources was the maximum difference in their light quality. Where one source had a significant flow in a certain spectral band (blue and red in LED source), the other (HPS) had a minor flow, and vice versa. In accordance with the introduced hypothesis, the maximum difference in the light quality should have the maximum impact on the developmental stability of irradiated plants. At the end of the experiment (18.03.2016, on the $22^{\text {nd }}$ day) the number of leaves in the rosette and their length, the wet weight of the leaves and dry matter content, as well as the bilateral traits of parsley leaves were recorded.

Parsley has multi-compound leaves consisting of several clearly separated leaf blades (folioles), with each one being attached to a common axis (rachis) with its leafstalk. The root and lower stem parsley leaves are tripinnately compound with pinnatisected or bipinnatisected segments. Their ultimate parts have an oblong-ovate or nearly rhombic shape (Fig. 1).

Four bilateral traits of parsley leaves were analysed statistically (Fig. 2):

Trait 1 - the length of the first leafstalks of the first order $(\mathrm{L} 1, \mathrm{R} 1)$ extending from the rachis;

Trait 2 - the length of the second leafstalks of the first order (L2, R2) extending from the rachis;

Trait 3 - the length of the leafstalks of the second order extending from the first leafstalk of the first order outwards (L3, R3) of the leaf;

Trait 4 - the length of the leafstalks of the second order, extending from the first leafstalk of the first order inwards (L4, R4) of the leaf. 




Fig. 1. Rosette of parsley leaves

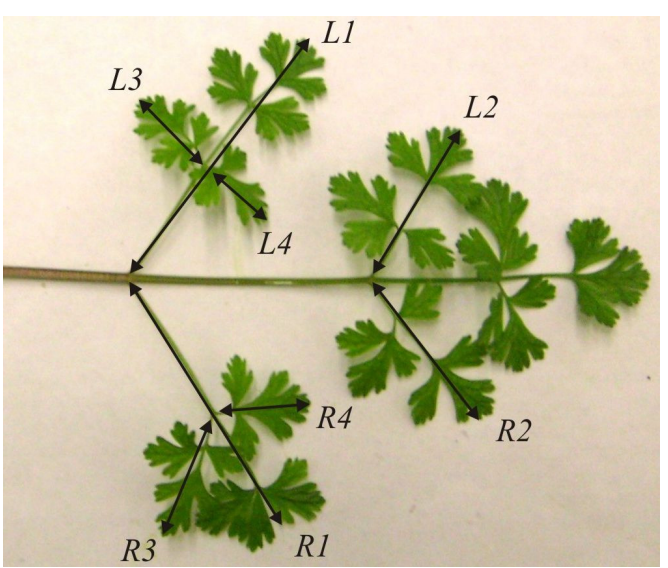

Fig. 2. Measured bilateral traits of a parsley leaf

The significance of biometric data differences was assessed with ANOVA. Statistical analysis of the evaluation results of fluctuating asymmetry included validation of data related to 1) normality of distribution of differences between the values of bilateral traits; 2) the presence of directional asymmetry; 3) the presence of anti-symmetry; 4) dependence of the trait asymmetry on its size; 5) correlation of traits; and 6) comparison of the FA level of parsley leaves, grown under the radiation with different light quality.

\section{Results}

The traits of 190 parsley leaves were measured, of which 93 leaves were grown under LED and 97 leaves were grown under HPS. Already the preliminary analysis of the data showed a fairly high incidence of asymmetric traits in parsley leaves grown under irradiation with different light quality (Table 1).

Table 1

Incidence of asymmetric traits in parsley leaves

\begin{tabular}{|c|c|c|c|c|}
\hline \multirow{2}{*}{$\begin{array}{c}\text { Trait } \\
\text { number }\end{array}$} & \multirow{2}{*}{$\begin{array}{c}\text { Light } \\
\text { source }\end{array}$} & \multirow{2}{*}{$\begin{array}{l}\text { Number of } \\
\text { samples }\end{array}$} & \multicolumn{2}{|c|}{ Indicator } \\
\hline & & & $\begin{array}{c}\text { Number of traits with } \\
\text { asymmetry }\end{array}$ & $\begin{array}{l}\text { Frequency of } \\
\text { occurrence }\end{array}$ \\
\hline \multirow{2}{*}{1} & LED & 93 & 79 & 0.85 \\
\hline & HPS & 97 & 77 & 0.79 \\
\hline \multirow{2}{*}{2} & LED & 93 & 55 & 0.59 \\
\hline & HPS & 97 & 56 & 0.58 \\
\hline \multirow{2}{*}{3} & LED & 93 & 65 & 0.70 \\
\hline & HPS & 97 & 70 & 0.72 \\
\hline \multirow{2}{*}{4} & LED & 93 & 57 & 0.61 \\
\hline & HPS & 97 & 51 & 0.53 \\
\hline
\end{tabular}

Normality test of the data distribution. Statistical analysis of asymmetry values distribution of bilateral traits of parsley leaves grown under both types of light sources was made by the fitting criteria of Kolmogorov-Smirnov, Shapiro-Wilk and Lilliefors tests and showed that the distribution of the majority of the received samples departed from normality (except for Trait 1 under HPS). So, the use of non-parametric statistical analysis was required.

Directional asymmetry test. The nonexistence of directional asymmetry is manifested in the fact that the distribution of bilateral trait differences is statistically homogeneous and approximately symmetrical with respect to zero. Direction of fluctuating asymmetry was verified by the Wilcoxon test. In none of the cases the statistically significant $(p<0.05)$ trait differences on the left and right side of the leaf were established. It means that there are fluctuations of trait asymmetry around zero that is diagnostic evidence of FA.

Test for antisymmetry. Th antisymmetry indicator was platykurtosis of distribution of L-R differences. Under $k \geq 0$ the hypothesis on the fluctuating nature of asymmetry was accepted. The 
analysis results showed the exceedance of the critical values of kurtosis of Trait 3 under HPS and Trait 4 under LED; but in these cases leptokurtosis was in place, so it could be argued that the analysed traits did not feature antisymmetry.

Test for size dependence. To identify the relationship between the value of the trait asymmetry $\mid \mathrm{L}-\mathrm{Rl}$ and its average size $(\mathrm{L}+\mathrm{R}) / 2$ we used the nonparametric Spearman's rank correlation coefficient $r_{S}$. Statistically significant $(p<0.05)$ correlation was observed only for Trait 4 under HPS. The occurrence of a size-dependent trait requires to use normalization of the form $I L-R l /(L+R)$, which is also convenient for not size-dependent traits as it provides a value of the asymmetry in the range $(0 \ldots 1)$.

Test for traits and their asymmetry correlation. This step of analysis allows to substantiate the inclusion of the studied trait in a set of traits, which integrally estimate FA of a plant: the less correlated the traits are, the clearer and reasonable estimation can be obtained through their set. The Spearman's rank coefficient was used in this test. As could be expected, natural values of traits on the left and right side of the leaf were closely correlated under statistical significance $p<0.05$ $\left(0.593 r_{S}<0.869\right.$ under LED and $0.745<r_{S}<0.910$ under HPS $)$. However, other natural values of traits are also significantly correlated $\left(0.478<r_{S}<0.833\right.$ under LED and $0.647<r_{S}<0.887$ under HPS). There was also significant correlation between asymmetries of the traits $\left(0.351<r_{S}<0.722\right.$ under LED and $0.251<r_{S}<0.624$ under HPS). This allowed to use only one trait to describe the FA of parsley leaves. For convenience of measurement it was advisable to take Trait 1 , which had the biggest size.

Biometric indicators. High productivity of parsley forcing was observed under HPS, where larger leaves with more wet weight were obtained. Table 2 shows the average values of the measured biometric indicators of forced parsley leaves with an average value and standard deviation of each indicator. The differences in wet weight of leaves, their length and level of FA were found statistically significant $(p<0.05)$.

Table 2

Results of the $t$-test of differences in average values of indicators

\begin{tabular}{|l|c|c|c|c|c|}
\hline \multirow{2}{*}{\multicolumn{1}{|c|}{ Indicator }} & \multicolumn{2}{c|}{ Average value } & \multicolumn{2}{c|}{ Standard deviation } & \multirow{2}{*}{$\boldsymbol{p}$} \\
\cline { 2 - 5 } & LED & HPS & LED & HPS & \multirow{2}{*}{0.629} \\
\hline Number of leaves, pieces & 7.8 & 7.4 & 1.8 & 2.8 & $<0.60$ \\
\hline Wet weight of leaves, g & 5.03 & 6.37 & 1.50 & 2.60 & $<\mathbf{0 . 0 5}$ \\
\hline Dry matter content, \% & 11.7 & 11.9 & 1.4 & 2.2 & 0.279 \\
\hline Leaf length (rachis), mm & 145.3 & 182.8 & 28.6 & 43.9 & $<\mathbf{0 . 0 5}$ \\
\hline Level of FA, relative unit & 0.052 & 0.039 & 0.043 & 0.031 & $<\mathbf{0 . 0 5}$ \\
\hline
\end{tabular}

\section{Discussion}

One of the types of environmental monitoring aimed at assessing the impact of various factors on the living environment is direct monitoring of growing plants or phytomonitoring. Environmental monitoring of natural populations makes wide use of fluctuating asymmetry phenomenon [9]. Subtle and non-directional deviations from the strict bilateral symmetry become more evident under the stronger external influence, anthropogenic pollution, in the first place. So they may be used to estimate the developmental stability of the organism [10]. In this respect, developmental destabilization begins to appear already under relatively low environmental disturbances, which are not yet associated with irreversible changes in the organism. This allows to use the FA as an indicator of the developmental stability of the organisms, which characterizes even minor deviations of environmental parameters from the baseline state $[11 ; 12]$.

The relationship between the FA level for plants, growing under natural conditions, and environmental factors is described in detail in scientific papers. Meanwhile, this issue has not been addressed yet for the indoor plant lighting conditions. Light is the most important environmental factor affecting the plant growth and biomass production. Sun is the natural source of radiation. The photons with shorter wavelength have considerable power and could have a damaging effect on biological objects (plants), but they are filtered by the ozone layer of the stratosphere. The photons with longer wavelength radiation have no sufficient energy to initiate the photosynthesis reaction. Insufficient light 
intensity or poor light quality impairs the growth and development of plants. For additional lighting of plants in greenhouses and under intensive indoor plant lighting the desired irradiance level is achieved by using sodium, metal halide or fluorescent lamps. These light sources are quite effective devices for converting the electrical energy into the integral energy of the photon flux. The light quality of their radiation, however, is far from the real needs of green plants in the radiation energy within different bands of PAR. A number of photo-biological studies, undertaken on some cultivated crops, produced the spectral ratios for their best possible productivity. Well-known laws can predict individual plant response to radiation effect of certain spectral bands. Thus, the blue light reduces stem elongation and prevents an increase in the plant leaf area. Green light has greater penetrating power that results in more intensive photo-physiological processes in the canopy. Yellow light leads to a strong plant elongation, longer hypocotyl and first internodes. Red light promotes the hypocotyl elongation and an increase of the leaf area. It is more difficult to predict the general plant response to the radiation with combined light quality due to the complex interaction of plant responses to the light of certain PAR bands [13].

In this study we evaluated the effect of different light quality of the radiation on the FA level and the productivity of parsley grown (forced) in the conditions of indoor plant lighting for the greens. One trait - the length of the first leafstalks of the first order extending from the rachis - was chosen out of the four studied traits of parsley leaves for further consideration. The smaller values of FA level by this trait turned out to correspond to bigger productivity of the plant. To assess the compliance of the numerical value of the FA level and the quality of plant growing environment the five-grade scale was designed [14]. According to this scale, the following qualities of the environment are recognised: conditionally normal (I grade FA < 0.040), minor deviations from the norm (II grade, $\mathrm{FA}=0.040-0.044$ ), the average deviation (III grade, $\mathrm{FA}=0.045-0.049$ ), significant deviations from the norm (IV grade, FA $=0.050-0.054)$, the critical state $(\mathrm{V}$ grade $\mathrm{FA}>0.054)$. When the obtained data were compared with this scale, it was found that the radiation of HPS lamp corresponded to the normal quality of the environment for plant growing (I grade), while LED application resulted in significant deviations from the norm (IV grade) that was manifested in the reduction of plant productivity.

The obtained experimental data and methods may be used as a part of the monitoring technique of energy and ecological efficiency of indoor plant lighting [15].

\section{Conclusions}

1. The essential asymmetry of forced parsley leaves under radiation with different light quality was identified. The frequency of occurrence of the length asymmetry in the largest folioles and segments of a multi-compound parsley leaf was from 53 to $85 \%$.

2. The nondirectedness of asymmetry of bilateral traits and the absence of anti-symmetry was proved. This fact allowed to identify the observed asymmetry as fluctuating.

3. Significant correlation between individual bilateral traits was revealed giving reason to take only one trait - the length of the first leafstalks of the first order extending from the rachis - to provide insight into the FA of parsley leaves. The size-dependence of this trait was not found.

4. The leaves of the plants grown under LED demonstrated statistically valid smaller weight and shorter rachis as compared to the plants grown under HPS. At the same time, the FA level in them was bigger. This confirmed the initial hypothesis that higher values of the FA level are observed in conditions, which are less favourable for plants.

5. FA level of leaves may be used to assess the quality of the parsley growing environment. The FA level might also be a diagnostic parameter of suitability of the light quality of radiation sources for cultivated crops in the indoor plant lighting.

\section{Acknowledgements}

Publication is created with support of European Regional Development Fund project "New control methods for energy and ecological efficiency increase of greenhouse plant lighting systems (uMOL)", Grant Agreement Nr. 1.1.1.1/16/A/261. 


\section{References}

1. Smith H. Light quality, photoperception, and plant strategy. Annu. Rev. Plant Physiol, 1982. v.33. pp. 481-518.

2. Будаговский А.В., Соловых Н.В., Будаговская О.Н., Будаговский И.А. Реакция растительных организмов на воздействие квазимонохроматического света с различными длительностью, интенсивностью и длиной волны (Response of plant organisms to the impact of quasi-monochromatic light with different duration, intensity and wavelength). Квантовая электроника, 2015, v.45, № 4. pp. 345-350. (In Russian)

3. Palmer A.R., Strobeck C. Fluctuating asymmetry analysis revisited. Developmental instability (DI): causes and consequences. M. Polak, ed. Oxford University Press, New York, 2003.

4. Светлакова Т.Н., Мандрица С.А., Боронникова С.В., Суслонов А.В. Оценка изменчивости морфологических признаков Trifolium pratense L. в условиях нефтяного загрязнения почв (Assessment of variability of morphological traits of Trifolium pratense L. in conditions of oil pollution of soil). Университет им. В.И. Вернадского, 2019, №1-3 (28). pp. 16-22. (In Russian)

5. Кузнецова Е.А., Челпанова О.М., Белова Е.Е., Хотулева О.В., Колонцов А.А. Оценка влияния ионов кадмия на флуктуирующую асимметрию листьев огурца посевного (Cucumis Sativus L.) (Assessment of the effect of cadmium ions on fluctuating asymmetry of leaves of field-seeded cucumber (Cиситis Sativus L.). Вестник МГОУ, 2013, №2. pp. C.1-9. (In Russian)

6. Ракутько Е.Н., Ракутько С.А. Рост и фотоморфогенез петрушки корневой (Petroselinum tuberosum) под оптическим излучением различного спектрального состава (Growth and photomorphogenesis of root parsley (Petroselinum tuberosum) under optical radiation of different light quality). Известия Санкт-Петербургского государственного аграрного университета, 2015, №38. pp.298-304. (In Russian)

7. Потехин, Г.А., Харченко В.А., Пивоваров В.Ф. Особенности выращивания петрушки на зелень (Specific features of growing parsley greens). Овощи России, 2010, №3 (9). pp.42-47.

8. Харченко, В. Зимняя петрушка (Parsley in winter). Приусадебное хозяйство, 2010, №12. pp. 22-23. (In Russian)

9. Кряжева Н.Г., Чистякова Е.К., Захаров В.М. Анализ стабильности развития березы повислой в условиях химического загрязнения (Analysis of developmental stability of drooping birch under conditions of chemical pollution). Экология, 1996, №6. pp. 441-444. (In Russian)

10. Зорина А.А., Коросов А.В Характеристика флуктуирующей асимметрии листа двух видов берез в Карелии. (Characteristics of fluctuating asymmetry of leaves of two species of birch-tree in Karelia). Экология. Экспериментальная генетика и физиология: тр. Карельс. науч. центра РАН. Петрозаводск, 2007, Вып. 11. pp. 28-36. (In Russian)

11. Захаров В.М., Чубинишвили А.Т., Дмитриев С.Г. и др. Здоровье среды: практика оценки.(Health of environment: practical assessment). М.: Центр экологической политики России, 2000. 320 p. (In Russian)

12. Четанов Н.А., Епланова Г.В. Статистический анализ флуктуирующей асимметрии билатеральных признаков живородящей ящерицы Zootoca Vivipara (Statistical analysis of fluctuating asymmetry of bilateral traits of common lizard Zootoca Vivipara). Известия Самарского научного центра РАН, 2011, т.13, №1. pp. 144-152. (In Russian)

13. Rakutko S., Rakutko E., Tranchuk A. Comparative evaluation of tomato transplant growth parameters under led, fluorescent and high-pressure sodium lamps. Proceedings 14-th International scientific conference Engineering for Rural Development, May 20-22, Jelgava, Latvia University of Agriculture, 2015, pp. 222-229.

14. Методические рекомендации по выполнению оценки качества среды по состоянию живых существ (оценка стабильности развития живых организмов по уровню асимметрии морфологических структур). (Guidelines for environment quality assessment by the condition of living beings (estimation of developmental stability of living organisms by the level of asymmetry of morphological structures). Утверждено Распоряжением Росэкологии от 16.10.2003 № 460-p. M., 2003. (In Russian)

15. Rakutko S., Rakutko E., Kaposhko D., Vaskin A. Monitoring technique of energy and ecological efficiency of indoor plant lighting. Proceedings 15-th International scientific conference Engineering for Rural Development, May 25-27, Jelgava, Latvia University of Agriculture, 2016, pp. 95-101. 